\title{
Oxidative Scission of the Disulfide Bond of Cystine and Polypeptides by the Action of Allyl Isothiocyanate
}

\author{
Shunro KaWAKISHI, Tamami Goto and Mitsuo NAMIKI \\ Department of Food Science and Technology, \\ Nagoya University, Nagoya 464, Japan
}

Received February 18, 1983

\begin{abstract}
The interaction of allyl isothiocyanate (1) with L-cystine and polypeptides under mild conditions was studied in detail. The reaction mixtures composed of isothiocyanate and cystine were incubated at 40,60 and $80^{\circ} \mathrm{C}$, in which cystine completely decomposed after 120,6 and $2 \mathrm{hr}$, respectively. Degradation products were isolated and identified as 2-allylamino-2-thiazoline-4carboxylic acid (2), 2-amino-2-thiazoline-4-carboxylic acid (3) and 3(3H)-allyl-5,6-dihydro-5amino-2(2H)-thioxo-1,3-thiazin-4-one (4). These products were formed through an oxidative scission of the disulfide bond in cystine by the electrophilic attack of allyl isothiocyanate; the products 2 and 4 seemed to be derived through alanyl $N$-allyldithiocarbamate and the product 3 through $\beta$-thiocyanoalanine. In addition, it was confirmed that a part of the disulfide bond in oxidized glutathione and insulin was also cleaved by isothiocyanate.
\end{abstract}

Mustard oils, alkyl isothiocyanates, have been formed from naturally occuring glucosinolates in the Cruciferae family by the action of myrosinase. ${ }^{1)}$ Among them, allyl isothiocyanate is a main pungent component of some spices such as horse radish, black mustard and Wasabi pastes. ${ }^{2)}$ Isothiocyanates are strong electrophilic reagents and rapidly react with some nucleophiles such as amine, amino acid, alcohol and water under physiological conditions. Most of isothiocyanates are not particularly stable and gradually decomposed to unpungent of malodorous products in their aqueous suspension. ${ }^{3 \sim 5)}$ The reaction of phen$y l$ isothiocyanate with the $\alpha$-amino group of the terminal amino acid in protein is well known and utilized as a method for the determination of amino acid sequence in protein. ${ }^{6,7)}$ Rapeseed (Brassica napus or B. campestris) is a most important oil seed and its defatted meal contains a high quality protein. This meal is nevertheless underestimated as an animal feed. ${ }^{8)}$ Among the many reasons, the following two problems related to the sulfur-containing compounds are considered; one is its goitrin contents and the other one is the interaction of isothiocyanates with meal protein. It is well- known that rapeseed contains several kinds of glucosinolates and that they are decomposed to isothiocyanates by the action of myrosinase when rape seeds are crushed. ${ }^{9,10}$ If such interaction arises in the crushed seeds, a part of seed protein will be transformed to modified protein by isothiocyanates, and it may be indigestible and/or a little cytotoxic. Therefore, the authors studied in detail the interaction of allyl isothiocyanate produced from sinigrin, the most widely distributed glucosinolate in the Cruciferae family, with certain amino acids and proteins under physiological conditions. The authors have already isolated and identified two kinds of thiazoline derivatives formed from the reaction of L-cystine and allyl isothiocyanate. ${ }^{11)}$ This paper concerns the oxidative scission of the disulfide bond of L-cystine, oxidixed glutathione and insulin by isothiocyanate.

\section{MATERIALS AND METHODS}

Reaction mixture. All reagents used in this study were Guaranteed Grade class and allyl isothiocyanate was distilled just before the preparation of the reaction mixture. L-Cystine $(0.1 \mathrm{mmol})$ and allyl isothiocyanate 
( $2.5 \mathrm{mmol})$ were suspended in a phosphate buffer solution (M/15, pH 6.0, $50 \mathrm{ml}$ ) and incubated at (a) $40^{\circ} \mathrm{C}$, (b) $60^{\circ} \mathrm{C}$ and (c) $80^{\circ} \mathrm{C}$ with vigorously stirring. The reaction processes were followed by the DTNB method, ${ }^{12,13)}$ which determined $\mathrm{SH}$ or $\mathrm{SOH}$ compounds as the reaction intermediates, and by TLC using Merck DC-Plastikfolien cellulose plates with a solvent system of $1-\mathrm{BuOH}: \mathrm{AcOH}$ : $\mathrm{H}_{2} \mathrm{O}=4: 1: 5(\mathrm{v} / \mathrm{v})$. The changes in the UV spectra of these reaction mixtures were also measured with a time course. The reaction mixtures of polypeptides and allyl isothiocyanate were prepared as follows: $80 \mu \mathrm{mol}$ of oxidized glutathione (Sigma, Grade III) and $0.8 \mathrm{mmol}$ of allyl isothiocyanate in $20 \mathrm{ml}$ of phosphate buffer $(\mathrm{pH} 6.0)$; $5 \mu \mathrm{mol}$ of insulin (Sigma, from bovine pancreas) and $0.5 \mathrm{mmol}$ of isothiocyanate in $25 \mathrm{ml}$ of phosphate buffer (pH 6.0) with or without $7 \mathrm{M}$ urea. They were both incubated at $40^{\circ} \mathrm{C}$.

Isolation of the reaction products. To isolate the reaction products, the suspension from $2 \mathrm{mmol}(240 \mathrm{mg})$ of $\mathrm{L}$ cystine and $20 \mathrm{mmol}(1.98 \mathrm{~g})$ of allyl isothiocyanate in $500 \mathrm{ml}$ of distilled water were prepared and incubated at $80^{\circ} \mathrm{C}$ with continuous stirring. After the cystine had disappeared from the TLC plate, the reaction mixture was extracted three times with ether and the aqueous layer was concentrated to dryness under reduced pressure. The pasty residue $(405 \mathrm{mg})$ was dissolved with methanol-water $(1: 2.5, \mathrm{v} / \mathrm{v})$ and submitted to preparative HPLC (Waters, ALC/GPC 202) equipped with a Bondapak $\mathrm{C}_{18}$ Porasil B column $(0.8 \times 120 \mathrm{~cm})$. Elution was carried out with methanol-water $(1: 2.5, \mathrm{v} / \mathrm{v}, 5 \mathrm{ml} / \mathrm{min})$ and further purification of each peak was performed by the use of a 10 ODS Develosil column $(0.8 \times 25 \mathrm{~cm})$ with methanol-water $(1: 9, \mathrm{v} / \mathrm{v}, 3 \mathrm{ml} / \mathrm{min})$.

$N M R$ and mass spectra. NMR spectra were measured with a JEOL model JNM FS-100 spectrometer. Mass spectrometry was performed by a JEOL model JMS D-100 spectrometer in the direct inlet mode under the following conditions: ionizing voltage, $75 \mathrm{eV}$; ionizing current, $300 \mu \mathrm{A}$; ion source temperature, $250^{\circ} \mathrm{C}$.

\section{RESULTS AND DISCUSSION}

Reaction of $\mathrm{L}$-cystine and allyl isothiocyanate under mild conditions

Aqueous suspensions of cystine and allyl isothiocyanate were incubated in 40, 60 and $80^{\circ} \mathrm{C}$ with vigorous stirring. The formation of the positive products for DTNB reagent in the reaction mixtures is shown in Fig. 1. They increased with increase in the reaction temperature, and reached their maxima for $70 \mathrm{hr}$ at $40^{\circ} \mathrm{C}, 4 \mathrm{hr}$ at $60^{\circ} \mathrm{C}$ and $1 \mathrm{hr}$ at $80^{\circ} \mathrm{C}$. The development of the DTNB positive products, which might have been $\mathrm{SH}$ or $\mathrm{SOH}$ compounds, suggested cleavage of the disulfide bond in cystine by the action of allyl isothiocyanate, and it was supported by the TLC analyses of the reaction mixtures (Fig. 2). Cystine completely disappeared after $120 \mathrm{hr}$ at $40^{\circ} \mathrm{C}, 6 \mathrm{hr}$ at $60^{\circ} \mathrm{C}$ and $2 \mathrm{hr}$ at $80^{\circ} \mathrm{C}$, and some other ninhydron positive products were newly formed. The UV spectra also indicated that some new products having an absorption maximum near $270 \mathrm{~nm}$ were formed with the decomposition of allyl isothiocyanate

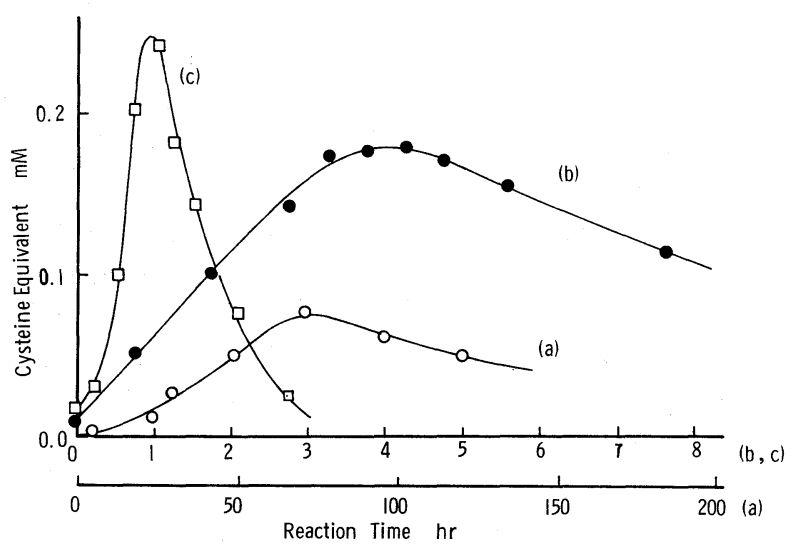

FIG. 1. Reaction of L-Cystine and Allyl Isothiocyanate.

The reaction mixture contained $0.1 \mathrm{mmol}$ of cystine and $2.5 \mathrm{mmol}$ of allyl isothiocyanate in $50 \mathrm{ml}$ of phosphate buffer solution ( $\mathrm{pH}$ 6.0). Reaction temperature: (a) $-\mathrm{O}-, 40^{\circ} \mathrm{C}$; (b) $-\mathrm{-}-60^{\circ} \mathrm{C}$; (c) - $\square-, 80^{\circ} \mathrm{C}$. Determination by the DTNB method. 


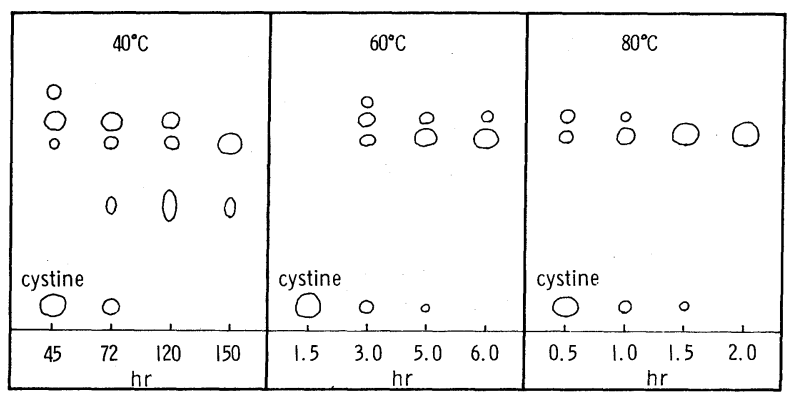

FIG. 2. TLC of Reaction Products in Time Course at 40,60 and $80^{\circ} \mathrm{C}$.

Plate, Merck DC-Plastikfolien Cellulose; solvent, 1- $\mathrm{BuOH}-\mathrm{AcOH}-\mathrm{H}_{2} \mathrm{O}=4: 1: 5, \mathrm{v} / \mathrm{v}$; color reagent, $0.2 \%$ ninhydrin ethanol solution.

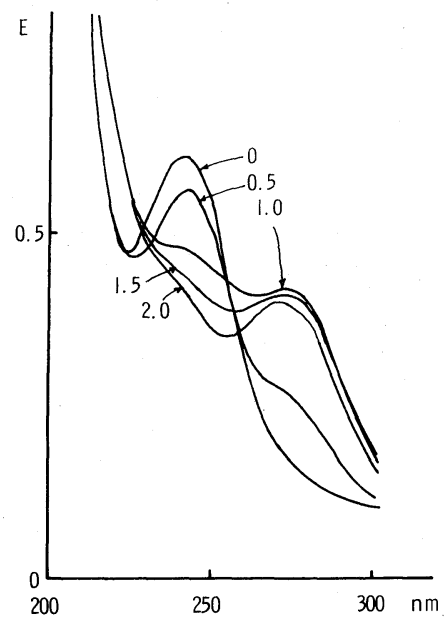

FIG. 3. UV Absorption Spectra of Reaction Mixture in Time Course at $80^{\circ} \mathrm{C}$.

Numbers in the figure show the reaction time in hour.

$\left(\lambda_{\max } \sim 240 \mathrm{~nm}\right)$ (Fig. 3). As the reaction progressed under mild conditions, both of cystine and allyl isothiocyanate were gradually decomposed, and the decomposition of cystine seemed to be caused by the scission of its disulfide, as judged from the color development with DTNB.

\section{Isolation and identification of the reaction products}

The products obtained from the reactions at temperatures between $40^{\circ}$ and $80^{\circ} \mathrm{C}$ were identical by TLC analyses, and isolation of the products was performed with the reaction mixture incubated at $80^{\circ} \mathrm{C}$. After ether extrac- tion of the reaction mixture to remove any unchanged isothiocyanate and ether soluble products, the aqueous layer was concentrated to dryness (dry matter $405 \mathrm{mg}$ ) and submitted to a preparative. HPLC. As shown in Fig. 4A, four peaks were obtained and among them, $\mathrm{P}_{2}$ gave a crystalline product by concentration (yield $64 \mathrm{mg}$ ), mp $186^{\circ} \mathrm{C}$ from methanol. Its structure was determined to be 2-allylamino-2thiazoline-4-carboxylic acid (2) from its IR, MS, ${ }^{1} \mathrm{H}$ NMR (acetone- $d_{6}, v s$. TMS) spectra and elementary analysis. ${ }^{11)} \mathrm{P}_{4}$ was also identified as $N, N^{\prime}$-diallylthiourea from a comparison of its IR spectrum with an authentic sample. This was a decomposition product of allyl isothiocyanate formed from the adduct of water to isothiocyanate. ${ }^{5)} \mathrm{P}_{1}$ (dry matter $102 \mathrm{mg}$ ) was shown to be a mixture of several products by TLC, and $P_{1}$ was separated to four peaks by repeated HPLC using the 10 ODS column (Fig. 4B), in which $P_{1-1}$ gave a crystalline product $(15 \mathrm{mg}), \mathrm{mp} 200 \sim 205^{\circ} \mathrm{C}$ (decomp.) from ethanol-water. This was identified as 2-amino-2-thiazoline-4-carboxylic acid (3) from its IR, MS, ${ }^{1} \mathrm{H}$ NMR $\left(\mathrm{D}_{2} \mathrm{O}+\mathrm{DCl}, v s\right.$. acetone) data and elementary analysis. ${ }^{11)}$ Data of $P_{1-1}$ agreed well with those of the synthetic compound obtained from Lcystine and potassium cyanide. ${ }^{14)}$

The concentrate $P_{1-3}$ (yield $7 \mathrm{mg}$ ), colorless paste, gave only one spot on TLC by ninhydrin and $\mathrm{I}_{2}$-azide reagents: $\mathrm{UV}, \max 275 \mathrm{~nm}$ (ethanol); IR, $v_{\max }^{\mathrm{KBr}} 1490,1380$ and $1040 \mathrm{~cm}^{-1}$ (thioamide), 940 and $980 \mathrm{~cm}^{-1}$ (allyl group); 


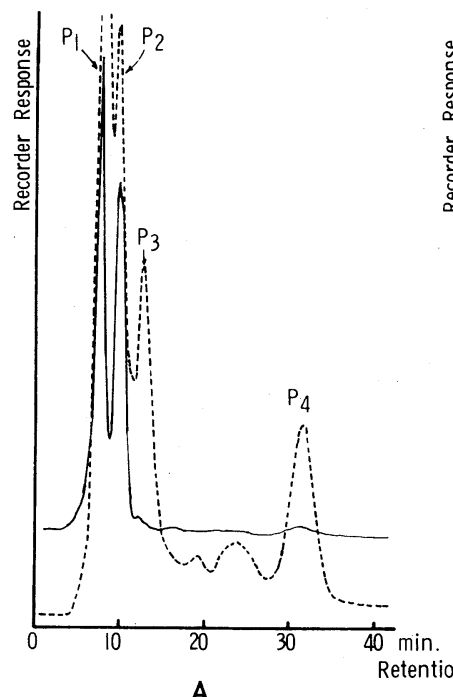

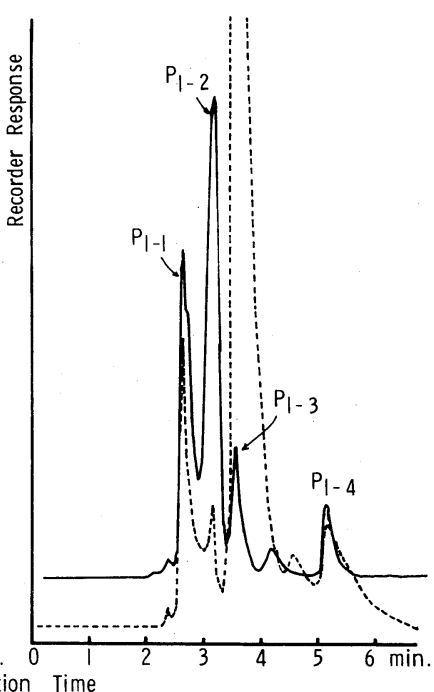

B

FIG. 4. HPLC of Reaction Products.

A: Sample, concentrate of ether-extracted reaction mixture; column, Bondapak $\mathrm{C}_{18}$ Porasil B; elution, methanol-water $=1: 2.5, \mathrm{v} / \mathrm{v}$.

B: Sample, $\mathrm{P}_{1}$ concentrate in A; column, 10 ODS Develosil; elution, methanol-water =1:9, v/v; — , RI detector; ------, UV $254 \mathrm{~nm}$.

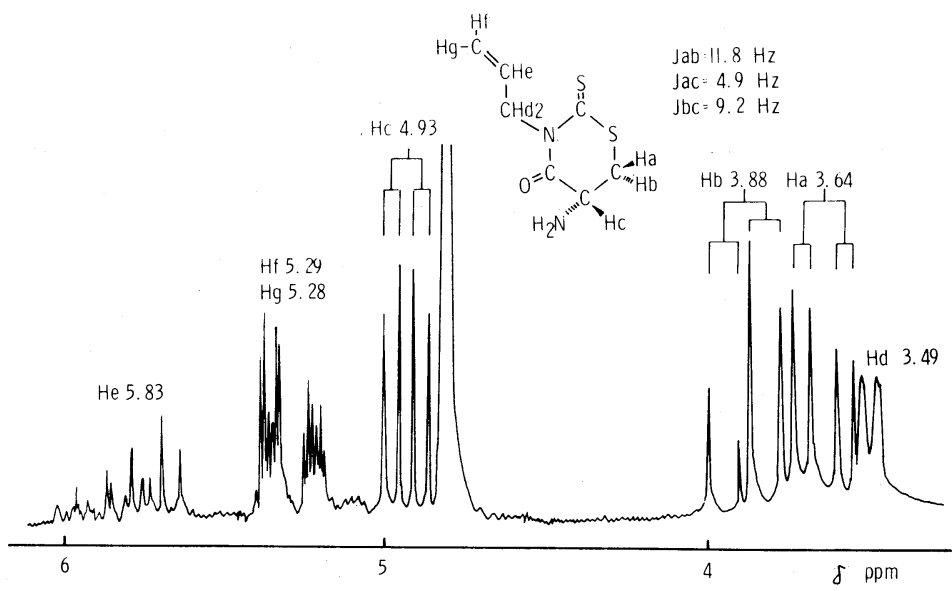

Fig. 5. ${ }^{1} \mathrm{H} \mathrm{NMR}$ of $\mathrm{P}_{1-3}$ (in $\mathrm{D}_{2}+\mathrm{DCl}$, vs. Acetone).

Anal. Found: C, 32.89; H, 5.33; N, 11.54; Calcd for $\mathrm{C}_{7} \mathrm{H}_{10} \mathrm{~N}_{2} \mathrm{OS}_{2} \cdot 3 \mathrm{H}_{2} \mathrm{O}: \mathrm{C}, 33.33 ; \mathrm{H}$, 6.25 ; N, $10.93 \%{ }^{1}{ }^{1} \mathrm{H}$ NMR showed the presence of an allyl group; $\delta 3.49(\mathrm{Hd}, 2 \mathrm{H} \mathrm{d}), 5.28$, $5.29(\mathrm{Hf}, \mathrm{Hg}, \mathrm{m}), 5.83(\mathrm{He}, \mathrm{m})$ and the ring protons due to the cystine residue; $\delta 3.64(\mathrm{Ha}$, dd $J=11.8,4.9 \mathrm{~Hz}), 3.88(\mathrm{Hb}$, dd $J=11.8,9.2$ $\mathrm{Hz}$ ) and 4.93 (Hc, dd $J=9.2,4.9 \mathrm{~Hz}$ ) (Fig. 5). This NMR data suggests the presence of a ring structure constituted from the cysteine residue in $P_{1-3}$ similarly to $P_{2}(2)$ and $P_{1-1}(3)$. From mass spectrometry, its molecular ion peak could not be detected, but several fragment peaks, $m / z 163(71 \%), 119(26 \%), 118(45 \%)$, $104(74 \%)$ and $86(100 \%)$ were abserved. Among them, the fragment ion, $m / z 163$, containing two sulfur atoms from $P+2 / P=0.09$, was suggested to be formed from the molec- 


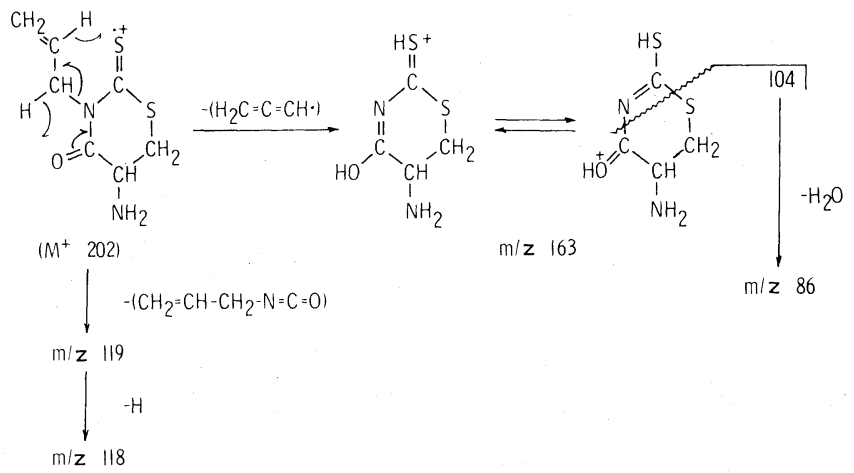

FIG. 6. Mass Fragmentation of $\mathrm{P}_{1-3}$.

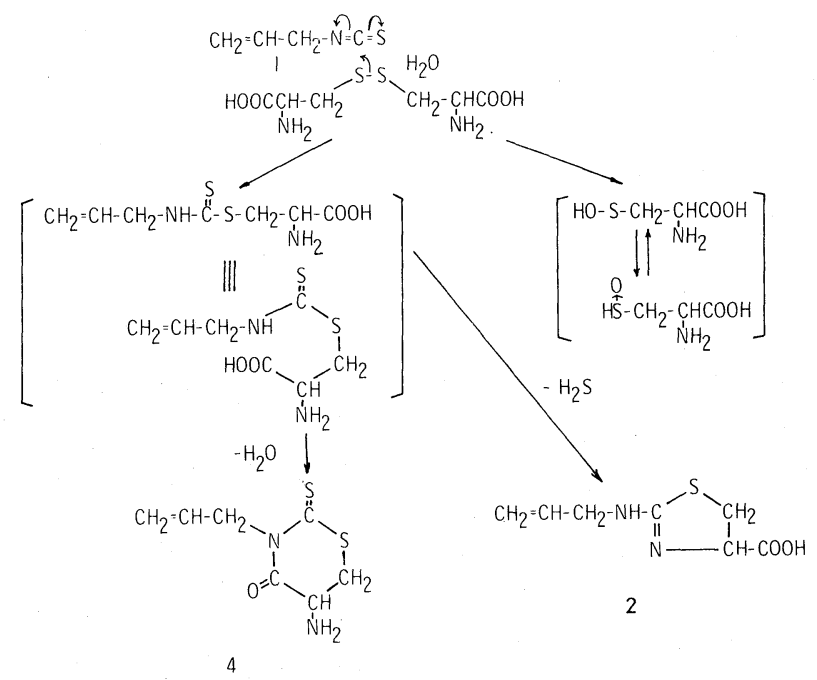

FIG. 7. Proposed Reaction Mechanism of Cystine and Allyl Isothiocyanate.

ular ion $(m / z$ 202, not observed) by two hydrogen transfer on its McLafferty rearrangement as shown in Fig. 6, and the formation of other fragment ions could be interpreted from this fragmentation scheme. Therefore, the structure of $\mathrm{P}_{1-3}$ was proposed as $\quad 3(3 H)$-allyl-5,6-dihydro-5-amino-2(2H)thioxo-1,3-thiazin-4-one (4) as shown in Figs. 5 and 6.

$\mathrm{P}_{1-2}$ in Fig. 4B was the largest peak in this fraction and also gave a crystalline product, but its structure remained unknown, and $\mathrm{P}_{1-4}$ was identified as $\mathbf{2}$ from its retention time.

Proposed reaction mechanism of cystine and allyl isothiocyanate

These results suggest that the reaction be- tween cystine and allyl isothiocyanate under mild conditions will proceed as follows: Isothiocyanate (1), a strong electrophile, may attack the disulfide bond of cystine and cause its oxidative cleavage to form alanyl $N$-allyl dithiocarbamate and sulfenoalanine. The former will rapidly cyclize to the thiazoline derivative (2) by releasing hydrogen sulfide ${ }^{11}$ ) and the 1,3-thiazine derivative (4) by dehydration as shown in Fig. 7. The formation of sulfenoalanine as an intermediate was not confirmed, but the characteristic color reaction of the reaction mixture with DTNB suggested its formation, since cysteine could not be produced in this oxidative reaction. The formation of 3 must have been due to the reaction of cystine and allyl thiocyanate isomerized 


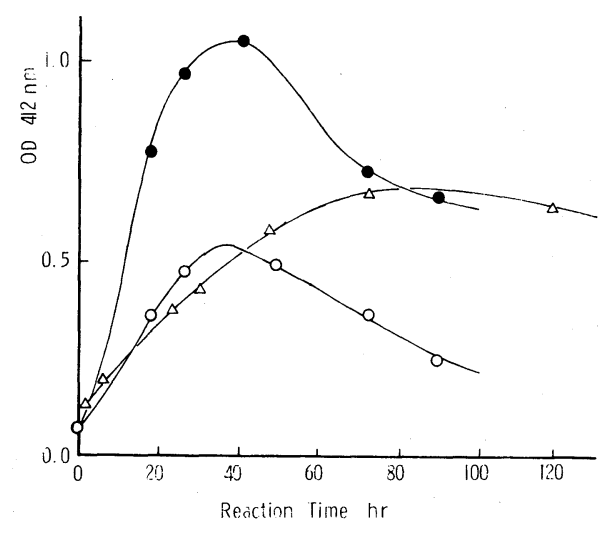

FIG. 8. Reaction of Oxidized Glutathione and Insulin with Allyl Isothiocyanate.

Reaction mixtures; $80 \mu \mathrm{mol}$ of oxidized glutathione and $0.8 \mathrm{mmol}$ of allyl isothiocyanate in $20 \mathrm{ml}$ of phosphate buffer solution ( $\mathrm{pH} 6.0)(-\triangle-) ; 5 \mu \mathrm{mol}$ of insulin and 0.5 mmol of isothiocyanate in $25 \mathrm{ml}$ of phosphate buffer solution ( $\mathrm{pH} \mathrm{6.0)}$ with (-O-) and without (-O-) $7 \mathrm{M}$ urea.

partially from isothiocyanate as was described in the previous paper. ${ }^{11)}$

\section{Oxidative cleavage of the disulfide bond in oxidized glutathione and insulin}

To confirm whether cleavage of the disulfide bond in protein will occur by electrophilic attack of isothiocyanate or not, the reactions of isothiocyanate with oxidized glutathione and insulin, composed from two peptide chains through the disulfide bond in the cystine residue, were investigated. Their reaction mixtures with allyl isothiocyanate were incubated in $40^{\circ} \mathrm{C}$ and their processes were followed by the color development with DTNB in a time course. The results (Fig. 8) show that the reaction between the disulfide bond of peptides and isothiocyanate pro- ceeded markedly and, especially, the color development of the insulin solution containing $7 \mathrm{M}$ urea as a denaturant was particularly noticable. These facts suggest that cleavage of the disulfide bond in these peptides may occur in the same manner with cystine by the attack of isothiocyanate. The details on this reaction will be presented elsewhere.

Acknowledgments. This work was supported in part by a Grant-in-Aid for Scientific Research from the Ministry of Education, Science and Culture of Japan. The authors wish to thank Dr. T. Hayashi of this Department for his useful advice and measurements of the NMR spectra.

\section{REFERENCES}

1) M. G. Ettlinger, G. P. Dateo, Jr., B. W. Harrison, T. J. Mabry and C. P. Thompson, Proc. Natl. Acad. Sci. U.S.A., 47, 1875 (1961).

2) Z. Nagashima, Nippon Nôgeikagaku Kaishi, 28, 119 (1954).

3) S. Kawakishi and K. Muramatsu, Agric. Biol. Chem., 30, 688 (1966).

4) S. Kawakishi, M. Namiki, H. Watanabe and K. Muramatsu, Agric. Biol. Chem., 31, 832 (1967).

5) S. Kawakishi and M. Namiki, Agric. Biol. Chem., 33, 452 (1969).

6). P. Edman, Arch. Biochem. Biophys., 22, 475 (1949).

7) P. Edman, Acta Chem. Scand., 4, 283 (1950).

8) T. Matsumoto, Jan. J. Zootech. Sci., 48, 691 (1977).

9) A. Kjaer, J. Conti and K. A. Jensen, Acta Chem. Scand., 7, 1271 (1953).

10) A. Kjaer and R. B. Jensen, Acta Chem. Scand., 10, 1365 (1956).

11) S. Kawakishi and M. Namiki, J. Agric. Food Chem., 30, 618 (1982).

12) G. L. Ellman, Arch. Biochem. Biophys., 82, 70 (1959).

13) J. Janatova, J. K. Fuller and M. J. Hunter, J. Biol. Chem., 243, 3612 (1968).

14) G. R. Jacobson, M. H. Schaffer, G. R. Strak and T. C. Vanaman, J. Biol. Chem., 248, 6583 (1973). 